\title{
Incidence and risk of severe infections associated with anti-epidermal growth factor receptor monoclonal antibodies in cancer patients: a systematic review and meta-analysis
}

Wei-Xiang $\mathrm{Qi}^{1}$, Shen $\mathrm{Fu}^{1,2^{*}}$, Qing Zhang ${ }^{1}$ and Xiao-Mao Guo ${ }^{1,2^{*}}$

\begin{abstract}
Background: Anti-epidermal growth factor receptor (EGFR)-monoclonal antibodies (MoAbs) have been widely used in a variety of malignancies. Severe infections ( $\geq$ grade 3 ) are potentially life-threatening adverse events with these drugs. However, the contribution of anti-EGFR MoAbs to infections is still unknown. We performed this meta-analysis to determine the overall incidence and risk of severe infections in cancer patients treated with these drugs.

Methods: The databases of PubMed and abstracts presented at oncology conferences and published in the proceedings were searched for relevant studies from January 2000 to May 2014. Summary incidences, relative risks (RRs) and $95 \%$ confidence intervals (Cls) were calculated by using either random effects or fixed effect models according to the heterogeneity of included studies.

Results: A total of 14,066 patients from 26 randomized controlled trials (RCTs) were included. The use of anti-EGFR-MoAbs significantly increased the risk of developing severe infections (RR 1.34,95\%Cl: 1.10 to $1.62, P=0.003$ ) in cancer patients, but not for fatal infections (RR $1.62,95 \% \mathrm{Cl}$ : 0.81 to $3.26, P=0.18$ ). Meta-regression indicated the infections might possibly occur early in the treatment with anti-EGFR MoAbs. On sub-group analysis, the risk of severe infections significantly varied with tumor type $(P=0.001)$. When stratified by specific anti-EGFR MoAbs, a significantly increased risk of infections with cetuximab was observed $(P<0.001)$, but not for panitumumab $(P=0.98)$. Additionally, the use of anti-EGFR MoAbs significantly increased the risk of severe infections when used in conjunction with cisplatin (RR $1.48,95 \% \mathrm{Cl} 1.22$ to $1.79, P<0.001$ ) or irinotecan (RR $1.53,95 \% \mathrm{Cl} 1.12$ to $2.10, P=0.008$ ). When stratified by specific infectious events, anti-EGFR-MoAbs significantly increased the risk of developing severe sepsis (RR 4.30, 95\%Cl: 1.80 to 10.27; $P=0.001$ ).
\end{abstract}

Conclusions: Anti-EGFR MoAbs treatment significantly increases the risk of developing severe infectious events in cancer patients. The risk may vary with tumor types. Clinicians should be aware of the risks of severe infections with the administration of these drugs in cancer patients.

Keywords: Cetuximab, Panitumumab, Anti-EGFR monoclonal antibody, Infections, Cancer, Meta-analysis

\footnotetext{
* Correspondence: fushen2014@sina.com; 121921900@qq.com

${ }^{1}$ Department of Radiation Oncology, Shanghai Proton and Heavy lon Center, 4365 Kang Xin Road, Shanghai 201318, China

${ }^{2}$ Department of Radiation Oncology, Fudan University Shanghai Cancer

Center, 270 Dong'An Road, Shanghai 200032, China
} 


\section{Background}

The epidermal growth factor receptor (EGFR) signal pathway plays an essential role in tumor proliferation, differentiation, anti-apoptosis and metastasis [1-3]. For this reason, EGFR and the process of its receptor binding are regarded as attractive therapeutic targets in the treatment of cancers. Currently, two monoclonal antibodies (MoAbs) targeted at EGFR, the chimeric immunoglobulin G1 (IgG1) MoAb cetuximab and the fully humanized IgG2 MoAb panitumumab, have shown a relevant clinical effect in the treatment of a variety of malignancies. Cetuximab has been approved by the US Food and Drug Administration (FDA) for the treatment of metastatic colorectal cancer [4] and recurrent or metastatic head and neck cancer [5]. Panitumumab is approved by the FDA for the indication of advanced colorectal cancer [6].

In contrast with traditional chemotherapy agents, anti-EGFR-MoAbs do not usually produce systemic toxicities such as nausea, vomiting, diarrhea, alopecia, and bone marrow suppression. However, anti-EGFR-MoAbs exhibit some unique toxicities including rash $[7,8]$, hypomagnesemia [9-11], hypokalemia [12] and venous and arterial thromboembolic events [11]. Specifically, severe infections ( $\geq$ grade 3 ) are reported in both cetuximab and panitumumab trials as a common side effect, as a cause of treatment disruption, and in some cases led to fatalities [13-15]. However, to the best of our knowledge, the incidence and risk of severe infections with these drugs have not been systematically defined. Therefore, we performed this up-to-date meta-analysis of randomized controlled trials to determine whether the addition of anti-EGFRMoAbs to therapies increases the risk of severe and fatal infections in cancer patients.

\section{Methods}

\section{Data sources}

We searched the PubMed (data from 2000 to May 2014), Embase (data from 2000 to May 2014) and the Cochrane Library electronic databases. Key words were 'cetuximab', 'Erbitux', 'panitumumab', 'Vectibix', 'cancer', 'carcinoma', 'neoplasm', 'randomized controlled trial' and 'infections'. The search was limited to prospective randomized clinical trials published in English. We also searched abstracts containing the term 'cetuximab' and 'panitumumab' that were presented at the American Society of Clinical Oncology (ASCO) and European Society of Medical Oncology (ESMO) annual meetings from 2004 to 2014 to identify relevant studies. Additionally, we searched the clinical trial registration website [16] to obtain information on registered prospective trials. Each publication was reviewed and in cases of duplicate publications only the most complete, recent and updated report of the clinical trial was included in the meta-analysis.

\section{Study selection}

The primary goal of our study was to determine the overall incidence of severe and fatal infections ( $\geq$ grade 3 ) associated with approved anti-EGFR-MoAbs (cetuximab and panitumumab) and establish the association between treatment with anti-EGFR-MoAbs and the risk of developing severe and fatal infections. Thus, only prospective randomized controlled phase II and III trials evaluating approved anti-EGFR-MoAbs (cetuximab and panitumumab) in cancer patients with adequate data on severe or fatal infections were incorporated in the analysis. Phase I and single-arm phase II trials were excluded due to lack of control groups. Clinical trials that met the following criteria were included: (1) prospective randomized controlled phase II or III trials involving cancer patients; (2) participants assigned to treatment with or without approved antiEGFR-MoAbs (cetuximab and panitumumab) in addition to concurrent chemotherapy, radiotherapy or biological agent; and (3) available data regarding events or incidence of severe or fatal infections and sample size.

\section{Data extraction and clinical end point}

Data abstraction was conducted independently by two investigators (WXQ and SF), and any discrepancy between the reviewers was resolved by consensus. For each study, the following information was extracted: first author's name, year of publication, phase of trials, number of enrolled subjects, treatment arms, number of patients in treatment and control groups, underlying malignancy, median age, median treatment duration, median progressionfree survival, median overall survival and adverse outcomes of interest (severe and fatal infections). The following adverse outcomes were considered as infectious events and were included in the analyses: infections (not specified), febrile neutropenia, sepsis, septic shock, and pneumonia. Adverse events of severe infections ( $\geq$ grade 3 ), as assessed and recorded according to the National Cancer Institute's common terminology criteria (NCI-CTC) version 2 or 3 [17], which has been widely used in cancer clinical trials, were extracted for analysis.

\section{Statistical analysis}

For the calculation of incidence, the number of patients with infections in the anti-EGFR-MoAbs group and the total number of patients receiving anti-EGFR-MoAbs were extracted from the selected clinical trials; the proportion of patients with infections and 95\% confidence interval (CI) were derived for each study. To calculate relative risk (RR), patients assigned to anti-EGFR-MoAbs were compared only with those assigned to control treatment in the same trial. For one study that reported zero events in the treatment or control arm, we applied the classic half-integer correction to calculate the RR and variance [18]. We also conducted the following pre-specified subgroup analyses to 
find the potential risk factor of infections: tumor types, anti-EGFR-MoAbs, concomitant therapies and phase of trials. To assess the stability of results, sensitivity analysis was performed by sequential omission of individual studies. Additionally, to test whether effect sizes were moderated by differences in length of treatment, we have carried out meta-regressions with the difference in median length of experimental treatments (expressed in weeks) as the predictor and RR as the dependent variable. Between-study heterogeneity was estimated using the $X^{2}$-based $Q$ statistic [19]. Heterogeneity was considered statistically significant when $P_{\text {heterogeneity }}<0.1$. If heterogeneity existed, the pooled estimate calculated based on the random-effects model was reported using the DerSimonian et al. method [20]. In the absence of heterogeneity, the pooled estimate calculated based on the fixed-effects model was reported using the inverse variance method. A statistical test with a $P$-value less than 0.05 was considered significant. The presence of publication bias was evaluated by using the Begg and Egger tests [21]. All statistical analyses were performed by using Version 2 of the Comprehensive MetaAnalysis program (Biostat, Englewood, NJ, USA) and Open Meta-Analyst software version 4.16.12 (Tufts University, Medford, MA, USA).

\section{Results}

\section{Search results}

Our search yielded 190 clinical studies relevant to cetuximab and panitumumab. After excluding review articles, phase I studies, single-arm phase II trials, case reports, editorials, meta-analyses and systematic reviews (Figure 1), we selected 26 randomized controlled trials
(RCTs), which included 17 phase III and 9 phase II trials. A total of 14,060 patients from 26 RCTs were included for analysis. The characteristics of the patients and studies are listed in Table 1. According to the inclusion criteria of each trial, patients were required to have adequate hepatic, renal and hematological function. Underlying malignancies included colorectal cancer (eleven trials) [14,15,22-31], non-small-cell lung cancer (seven trials) [32-38], head and neck cancer (four trials) $[5,13,39,40]$, breast cancer (one trial) [41], urothelial carcinoma (one trial) [42], pancreatic cancer (one trial) [43] and esophagogastric cancer (one trial) [44].

\section{Overall incidence of severe and fatal infections}

For calculating the incidence of severe infections, a total of 6,446 patients from 26 RCTs who received anti-EGFR-MoAbs were included for analysis. Using a random-effects model, the summary incidence of severe infection was $8.1 \%$ (95\%CI, 6.0 to 10.9\%). In addition, severe infections can be fatal in many instances. A total of 5,239 patients from 16 RCTs were included for analysis of fatal infections. Fatal infections occurred in 24 patients, representing a total incidence of $0.8 \%$ (95\%CI: $0.5 \%$ to $1.2 \%$ ). Among patients with anti-EGFR MoAbs-associated severe infections, meta-analysis showed that the mortality of severe infections associated with anti-EGFR MoAbs was $4.0 \%$ (95\%CI: 2.7 to $5.9 \%$ ).

\section{Relative risk of severe and fatal infections}

To determine the specific contribution of anti-EGFR MoAbs to the development of infections and to exclude the effect of any confounding factors, we calculated the

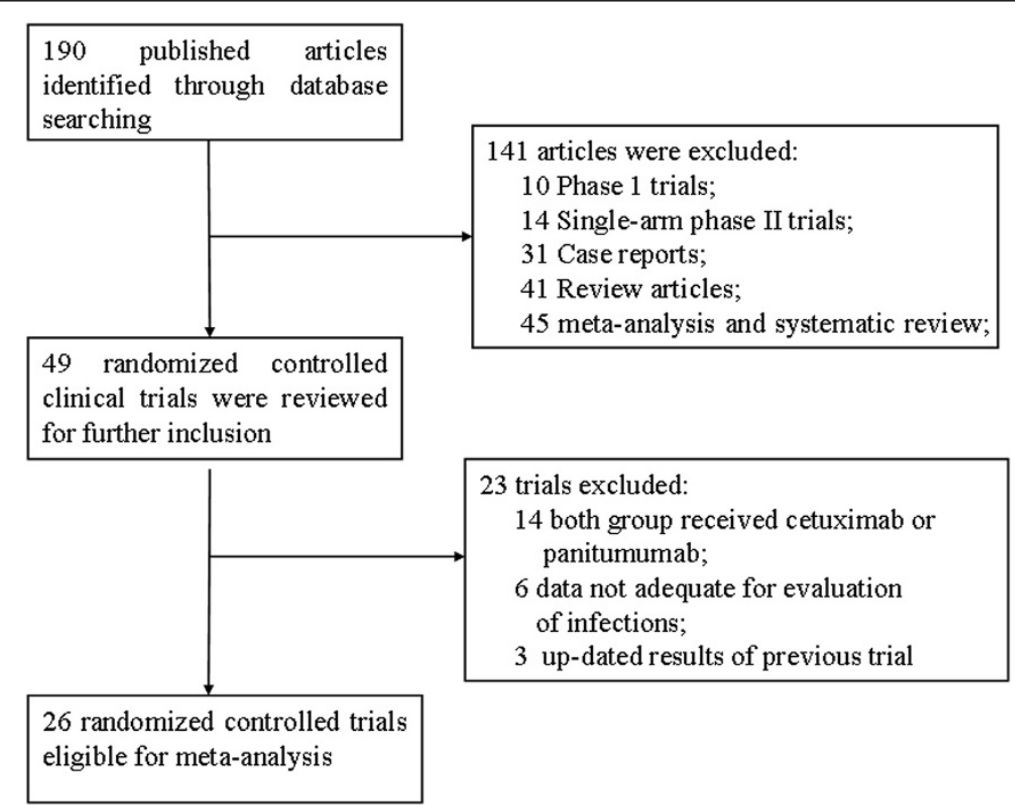

Figure 1 Selection process for prospective randomized controlled trials included in the meta-analysis. 
Table 1 Baseline characteristics of 26 randomized controlled trials in the meta-analysis (number $=14,060$ )

\begin{tabular}{|c|c|c|c|c|c|c|c|c|c|c|}
\hline Authors/year/phase & Histology & $\begin{array}{l}\text { Patients } \\
\text { enrolled }\end{array}$ & Treatment aim & $\begin{array}{l}\text { Median } \\
\text { age, years }\end{array}$ & $\begin{array}{l}\text { Median } \\
\text { duration, } \\
\text { weeks }\end{array}$ & $\begin{array}{l}\text { Median } \\
\text { PFS, } m\end{array}$ & $\begin{array}{l}\text { Median } \\
\text { OS, m }\end{array}$ & $\begin{array}{l}\text { Number } \\
\text { for analysis }\end{array}$ & $\begin{array}{l}\text { Severe } \\
\text { infections }\end{array}$ & $\begin{array}{l}\text { Reported infectious } \\
\text { events }\end{array}$ \\
\hline \multirow[t]{2}{*}{ Burtness B. et al./2005/III } & $\begin{array}{l}\text { Head and } \\
\text { neck cancer }\end{array}$ & 117 & Cetuximab + DDP & 60.6 & 4.5 & 4.2 & 9.2 & 58 & 15 & Infections \\
\hline & & & Placebo + DDP & 58.3 & 3 & 2.7 & 8 & 58 & 10 & \\
\hline \multirow[t]{2}{*}{ Bonner J.A. et al./2006/III } & $\begin{array}{l}\text { Head and } \\
\text { neck cancer }\end{array}$ & 424 & Cetuximab + radiotherapy & 56 & 8 & 24.4 & 49 & 208 & 1 & Infections \\
\hline & & & Radiotherapy & 58 & $N R$ & 14.9 & 29.3 & 212 & 1 & \\
\hline \multirow[t]{2}{*}{ Jonker D. J. et al./2007/III } & CRC & 572 & Cetuximab + BSC & 63 & 8.1 & NR & 6.1 & 288 & 37 & Infections \\
\hline & & & BSC & 63.6 & NR & NR & 4.6 & 274 & 15 & \\
\hline \multirow[t]{2}{*}{ Borner M. et al./2008/II } & CRC & 74 & $\begin{array}{l}\text { Cetuximab + oxaliplatin + } \\
\text { capecitabine }\end{array}$ & 60 & 18 & 7.2 & 20.5 & 37 & 0 & Febrile neutropenia \\
\hline & & & Oxaliplatin + capecitabine & 63 & 18 & 5.8 & 16.5 & 37 & 0 & \\
\hline \multirow[t]{2}{*}{ Rosell R. et al./2008/II } & NSCLC & 86 & Cetuximab + NVB + DDP & 58 & 13.6 & 5 & 8.3 & 42 & 7 & Infections \\
\hline & & & $\mathrm{NVB}+\mathrm{DDP}$ & 57 & 12 & 4.6 & 7.3 & 43 & 2 & \\
\hline \multirow[t]{2}{*}{ Sobrero A.F. et al./2008/III } & CRC & 1298 & Cetuximab + irinotecan & 61 & 14 & 4 & 10.7 & 638 & 49 & Febrile neutropenia \\
\hline & & & Irinotecan & 62 & 13.1 & 2.6 & 10 & 629 & 39 & \\
\hline \multirow[t]{2}{*}{ Vermorken J.B. et al./2008/III } & $\begin{array}{l}\text { Head and } \\
\text { neck cancer }\end{array}$ & 422 & Cetuximab + platinum + FU & 56 & 18 & 5.6 & 10.1 & 219 & 28 & $\begin{array}{l}\text { Febrile neutropenia, } \\
\text { pneumonia, sepsis }\end{array}$ \\
\hline & & & Platinum + FU & 57 & 15 & 3.3 & 7.4 & 215 & 15 & \\
\hline \multirow[t]{2}{*}{ Lienbaum R. et al./2009/II } & NSCLC & 64 & Cetuximab + PTX & NR & 16 & 3.4 & NR & 30 & 1 & Infections \\
\hline & & & Bortezomib + PTX & NR & 8 & 1.9 & NR & 29 & 1 & \\
\hline \multirow[t]{2}{*}{ Pirker R.et al./2009/III } & NSCLC & 1125 & Cetuximab + NVB + DDP & 59 & 18 & NR & 11.3 & 548 & 129 & Febrile neutropenia, \\
\hline & & & $\mathrm{NVB}+\mathrm{DDP}$ & 60 & 14 & NR & 10.1 & 562 & 90 & \\
\hline \multirow[t]{2}{*}{ Tol J. et al./2009/III } & CRC & 755 & $\begin{array}{l}\text { Cetuximab + capecitabine + } \\
\text { oxaliplatin + Bev }\end{array}$ & 62 & 30 & 10.7 & 20.3 & 366 & 22 & Infections \\
\hline & & & Capecitabine + oxaliplatin + Bev & 62 & 25.7 & 9.4 & 19.4 & 366 & 25 & \\
\hline \multirow[t]{2}{*}{ Lynch T.J. et al./2010/III } & NSCLC & 676 & Cetuximab + chemotherapy & 64 & 13 & 4.4 & 9.69 & 325 & 15 & Febrile neutropenia \\
\hline & & & Chemotherapy & 65 & 12 & 4.24 & 8.38 & 320 & 11 & \\
\hline \multirow[t]{2}{*}{ Govindan R. et al./2011/II } & NSCLC & 101 & Cetuximab + chemoradiotherapy & 66 & NR & 12.3 & 22.2 & 53 & 9 & Febrile neutropenia, \\
\hline & & & Chemoradiotherapy & 65 & NR & 12.6 & 22.4 & 50 & 10 & \\
\hline \multirow[t]{2}{*}{ Alberts S.R. et al./2012/III } & CRC & 2686 & Cetuximab + FOLFOX & NR & NR & NR & $N R$ & 931 & 96 & Infections, febrile \\
\hline & & & FOLFOX & NR & NR & NR & NR & 894 & 45 & $\begin{array}{l}\text { neutropenia, } \\
\text { pneumonia }\end{array}$ \\
\hline
\end{tabular}


Table 1 Baseline characteristics of 26 randomized controlled trials in the meta-analysis (number $=14,060)($ Continued)

\begin{tabular}{|c|c|c|c|c|c|c|c|c|c|c|}
\hline \multirow[t]{2}{*}{ Dewdney A. et al./2012/II } & CRC & 165 & $\begin{array}{l}\text { Cetuximab + capecitabine + } \\
\text { oxaliplatin + radiotherapy }\end{array}$ & 65 & NR & NR & $N R$ & 83 & 1 & \multirow[t]{2}{*}{ Febrile neutropenia } \\
\hline & & & $\begin{array}{l}\text { Capecitabine + oxaliplatin + } \\
\text { radiotherapy }\end{array}$ & 61 & NR & NR & $N R$ & 81 & 1 & \\
\hline \multirow[t]{2}{*}{ Saltz L. et al./2012/III } & CRC & 247 & Cetuximab + Bev + FOLFOX & 63.2 & NR & 8.3 & 19.5 & 121 & 1 & \multirow[t]{2}{*}{ Sepsis } \\
\hline & & & Bev + FOLFOX & 61.2 & NR & 11 & 21.3 & 118 & 1 & \\
\hline \multirow[t]{2}{*}{ Baselga J. et al./2013/II } & $M B C$ & 181 & Cetuximab + DDP & 53 & 13.6 & 3.7 & 12.9 & 114 & 2 & \multirow[t]{2}{*}{ Sepsis } \\
\hline & & & DDP & 52 & 13.1 & 1.5 & 9.4 & 57 & 0 & \\
\hline \multirow[t]{2}{*}{ Kim E.S. et al./2013/III } & NSCLC & 605 & Cetuximab + Pemetrexed & 64 & $N R$ & 2.9 & 6.9 & 292 & 35 & \multirow{2}{*}{$\begin{array}{l}\text { Infections, lung } \\
\text { infections, sepsis }\end{array}$} \\
\hline & & & Pemetrexed & 65 & NR & 2.8 & 7.8 & 289 & 23 & \\
\hline \multirow[t]{2}{*}{ Burtness B. et al./2014/II } & $\begin{array}{l}\text { Pancreatic } \\
\text { cancer }\end{array}$ & 87 & Cetuximab + Doc + irinotecan & 60 & 16.5 & 4.5 & 6.5 & 45 & 5 & \multirow[t]{2}{*}{$\begin{array}{l}\text { Febrile neutropenia, } \\
\text { infections }\end{array}$} \\
\hline & & & Doc + irinotecan & 60 & 14.5 & 3.9 & 5.3 & 46 & 4 & \\
\hline \multirow[t]{2}{*}{ Huang J. et al./2014/III } & CRC & 146 & Cetuximab + FOLFIRI & 57 & NR & NR & NR & 40 & 3 & \multirow{2}{*}{$\begin{array}{l}\text { Infections, febrile } \\
\text { neutropenia }\end{array}$} \\
\hline & & & FOLFIRI & 59 & NR & NR & NR & 106 & 3 & \\
\hline \multirow[t]{2}{*}{ Hussain M. et al./2014/II } & $\begin{array}{l}\text { Urothelial } \\
\text { carcinoma }\end{array}$ & 88 & Cetuximab + GEM + DDP & 60.9 & 21.4 & 7.6 & 14.3 & 59 & 7 & \multirow[t]{2}{*}{ Infections, pneumonia } \\
\hline & & & GEM + DDP & 65.8 & 21.4 & 8.5 & 17.4 & 28 & 3 & \\
\hline \multirow[t]{2}{*}{ van den Heuval M.M. et al./2014/II } & NSCLC & 102 & Cetuximab + chemoradiotherapy & 62 & NR & NR & NR & 51 & 3 & \multirow[t]{2}{*}{ Pneumonia } \\
\hline & & & Chemoradiotherapy & 63 & NR & NR & NR & 51 & 0 & \\
\hline \multirow[t]{2}{*}{ Douillard J.Y. et al./2010/III } & CRC & 1183 & Panitumumab + FOLFOX4 & NR & 20 & 9.6 & 23.9 & 539 & 15 & \multirow[t]{2}{*}{ Febrile neutropenia } \\
\hline & & & FOLFOX4 & NR & NR & 8.6 & 19.7 & 545 & 14 & \\
\hline \multirow[t]{2}{*}{ Peeters M. et al./2010/III } & CRC & 1186 & Panitumumab + FOLFIRI & NR & NR & 5.9 & 14.5 & 539 & 9 & \multirow[t]{2}{*}{ Febrile neutropenia } \\
\hline & & & FOLFIRI & NR & NR & 3.9 & 12.5 & 540 & 16 & \\
\hline \multirow[t]{2}{*}{ Seymour M. T. et al./2013/III } & CRC & 460 & Panitumumab + irinotecan & 64 & 12 & NR & 10.4 & 219 & 42 & \multirow[t]{2}{*}{ Infections } \\
\hline & & & Irinotecan & 63 & 12 & NR & 10.5 & 218 & 22 & \\
\hline \multirow[t]{2}{*}{ Vermorken J.B. et al./2008/III } & $\begin{array}{l}\text { Head and } \\
\text { neck cancer }\end{array}$ & 657 & Panitumumab + DDP + FU & 58 & 18.3 & 5.8 & 11.1 & 325 & 20 & \multirow[t]{2}{*}{ Febrile neutropenia } \\
\hline & & & $\mathrm{DDP}+\mathrm{FU}$ & 59 & NR & 4.6 & 9 & 325 & 17 & \\
\hline \multirow[t]{2}{*}{ Waddell T. et al./2013/III } & $\begin{array}{l}\text { Esophagogastric } \\
\text { cancer }\end{array}$ & 553 & $\begin{array}{l}\text { Panitumumab + epirubicin + } \\
\text { oxaliplatin + capecitabine }\end{array}$ & 63 & 15 & 7.4 & 8.8 & 276 & 48 & \multirow[t]{2}{*}{$\begin{array}{l}\text { Infection, febrile } \\
\text { neutropenia }\end{array}$} \\
\hline & & & $\begin{array}{l}\text { Epirubicin + oxaliplatin + } \\
\text { capecitabine }\end{array}$ & 62 & 15 & 6 & 11.3 & 266 & 70 & \\
\hline
\end{tabular}

Bev, bevacizumab; BSC, best support care; CRC, colorectal cancer; DDP, cisplatin; Doc, docetaxel; FOLFIRI, folinic acid (leucovorin), fluorouracil and irinotecan; FOLFOX, folinic acid (leucovorin), fluorouracil and oxaliplatin; Fu, fluorouracil; MBC, metastatic breast cancer; NR, not reported; NSCLC, non-small-cell lung cancer; NVB, vinorelbine; OS, overall survival; PTX, paclitaxel; PFS, progression free survival. 
overall RR of infections from these RCTs. For calculating RR of severe infections, 26 RCTs, representing 14,060 patients, were included. Among the 6,446 patients treated with anti-EGFR MoAbs, 601 presented with severe infections, whereas 438 of 6,359 patients in control groups had a severe infectious event. This conferred an overall $\mathrm{RR}$ of developing severe infections of 1.34 (95\%CI, 1.10 to $1.62 ; P=0.003$; Figure 2 ). Significant heterogeneity was observed in the RR analysis of severe infectious events $\left(\mathrm{Q}=44.99 ; P=0.006 ; I^{2}=46.7 \%\right)$. Considering fatal infectious events, 24 of 5,239 patients treated with anti-EGFR MoAbs and 11 of 4,940 patients in control arms experienced a fatal infection. This conferred an overall RR of 1.61 (95\%CI, 0.81 to $3.25 ; P=0.18$ ). No significant heterogeneity was observed in the RR analysis of fatal infections $\left(\mathrm{Q}=6.64 ; P=0.88 ; \mathrm{I}^{2}=0 \%\right)$. We also performed a sensitivity analysis to examine the stability and reliability of pooled severe RRs by sequential omission of individual studies. The results indicated that the significance estimate of pooled severe RRs was not significantly influenced by omitting any single study (Figure 3). Additionally, a meta-regression analysis was carried out to test whether the $R R$ of severe infections varied as a function of difference in the length of the experimental treatments. The result indicated that the RR of severe infections tended to be lower in the study in which the experimental treatment was longer, and this effect was statistically significant $(P=0.02$, Figure 4$)$.

\section{Sub-group analysis for relative risk of severe infections}

To determine whether the observed increase in RRs of developing severe infections was the result of confounding bias, we performed subgroup analyses according to the underlying malignancy, anti-EGFR-MoAbs, concomitant drugs and phase of trials. When stratified by tumor types, a significantly increased risk of severe infections was observed in colorectal cancer (RR1.42, 95\%: 1.05 to 1.93, $P=0.024$ ), non-small-cell lung cancer (RR1.45, 95\%: 1.19 to $1.77, P<0.001)$ and head and neck cancer (RR1.48, 95\%: 1.02 to $2.13, P=0.037$ ), while the risk of severe infections was decreased in other tumor types (RR $0.72,95 \%$ CI: 0.53 to $0.97, P=0.033$, Table 2 ). In addition, significant differences in RRs of severe infections were found among these tumor types $(P=0.001)$. However, clinicians should be cautious when interpreting these results due to limited RCTs of other tumor types included for the RR calculation.

The risk of severe infections might be related to different anti-EGFR MoAbs. Our results demonstrated that the use of cetuximab significantly increased the risk of severe infections (RR 1.52, 95\%CI: 1.33 to $1.75, P<0.001$ ), while the use of panitumumab did not increase the risk of severe infections (RR $0.99,95 \% \mathrm{CI}: 0.62$ to $1.60, P=0.98$ ). Then, we also carried out a subgroup risk analysis stratified according to concomitant therapies with anti-EGFR-MoAbs. A significantly increased risk of severe infections with antiEGFR-MoAbs was observed when used in conjunction with

\begin{tabular}{|c|c|c|c|c|c|c|c|}
\hline \multirow[t]{2}{*}{$\underline{\text { Study name }}$} & \multicolumn{5}{|c|}{ Statistics for each study } & \multicolumn{2}{|c|}{ Events / Total } \\
\hline & $\begin{array}{l}\text { Risk } \\
\text { ratio }\end{array}$ & $\begin{array}{l}\text { Lower } \\
\text { limit }\end{array}$ & $\begin{array}{c}\text { Upper } \\
\text { limit }\end{array}$ & Z-Value & p-Value & EGFR-MoAbs & control \\
\hline Burtness B. et al/2005/III & 1.500 & 0.736 & 3.059 & 1.115 & 0.265 & $15 / 58$ & $10 / 58$ \\
\hline Bonner J.A.et al/2006/III & 1.019 & 0.064 & 16.188 & 0.014 & 0.989 & $1 / 208$ & $1 / 212$ \\
\hline Jonker D.J. et al/2007/III & 2.347 & 1.318 & 4.178 & 2.899 & 0.004 & $37 / 288$ & $15 / 274$ \\
\hline Rosell R. et al/2008/II & 3.583 & 0.789 & 16.267 & 1.653 & 0.098 & $7 / 42$ & $2 / 43$ \\
\hline Sobrero A.F. et al/2008/III & 1.239 & 0.825 & 1.859 & 1.034 & 0.301 & $49 / 638$ & $39 / 629$ \\
\hline Vermorken J.B. et al/2008/III & 1.833 & 1.008 & 3.333 & 1.984 & 0.047 & $28 / 219$ & $15 / 215$ \\
\hline Lienbaum R. et al/2009/II/ & 0.967 & 0.063 & 14.739 & -0.024 & 0.981 & $1 / 30$ & $1 / 29$ \\
\hline Pirker R.et al/2009/III & 1.470 & 1.154 & 1.873 & 3.119 & 0.002 & $129 / 548$ & $90 / 562$ \\
\hline Tol J. et al/2009/III & 0.880 & 0.506 & 1.532 & -0.452 & 0.651 & $22 / 366$ & $25 / 366$ \\
\hline Lynch T.J. et al/2010/III & 1.343 & 0.626 & 2.878 & 0.757 & 0.449 & $15 / 325$ & $11 / 320$ \\
\hline Govindan R. et al/2011/II & 0.849 & 0.376 & 1.915 & -0.394 & 0.693 & $9 / 53$ & $10 / 50$ \\
\hline Alberts S.R. et al/2012/III & 2.049 & 1.455 & 2.884 & 4.110 & 0.000 & $96 / 931$ & $45 / 894$ \\
\hline Dewdney A. et al/2012/II & 0.976 & 0.062 & 15.340 & -0.017 & 0.986 & $1 / 83$ & $1 / 81$ \\
\hline Saltz L. et al/2012/III & 0.975 & 0.062 & 15.411 & -0.018 & 0.986 & $1 / 121$ & $1 / 118$ \\
\hline Baselga J. et al/2013/II & 2.522 & 0.123 & 51.669 & 0.600 & 0.548 & $2 / 114$ & $0 / 57$ \\
\hline Kim E.S. et al/2013/III & 1.506 & 0.913 & 2.484 & 1.604 & 0.109 & $35 / 292$ & $23 / 289$ \\
\hline Burtness B.et al/2014/II & 1.278 & 0.366 & & 0.385 & 0.700 & $5 / 45$ & $4 / 46$ \\
\hline Huang J. et al/2014/III & 3.533 & 0.827 & 15.095 & 1.704 & 0.088 & $4 / 40$ & $3 / 106$ \\
\hline Hussain M. et al/2014/II & 1.107 & 0.309 & 3.965 & 0.157 & 0.875 & $7 / 59$ & $3 / 28$ \\
\hline van den Heuval M.M. et al/2014/II & 7.000 & 0.371 & 132.166 & 1.298 & 0.194 & $3 / 51$ & $0 / 51$ \\
\hline Douillard J.Y. et al/2010/III & 1.083 & 0.528 & 2.222 & 0.218 & 0.827 & $15 / 539$ & $14 / 545$ \\
\hline Peeters M. et al/2010/III & 0.564 & 0.251 & 1.264 & -1.391 & 0.164 & $9 / 539$ & $16 / 540$ \\
\hline Seymour M.T.et al/2013/III & 1.900 & 1.175 & 3.073 & 2.619 & 0.009 & $42 / 219$ & $22 / 218$ \\
\hline vermorken J.B. et al/2008/III & 1.176 & 0.628 & 2.205 & 0.507 & 0.612 & $20 / 325$ & $17 / 325$ \\
\hline Waddell T. et al/2013/III & 0.661 & 0.477 & 0.916 & -2.487 & 0.013 & $48 / 276$ & $70 / 266$ \\
\hline & 1.339 & 1.104 & 1.624 & 2.965 & 0.003 & $601 / 6409$ & $438 / 6322$ \\
\hline
\end{tabular}

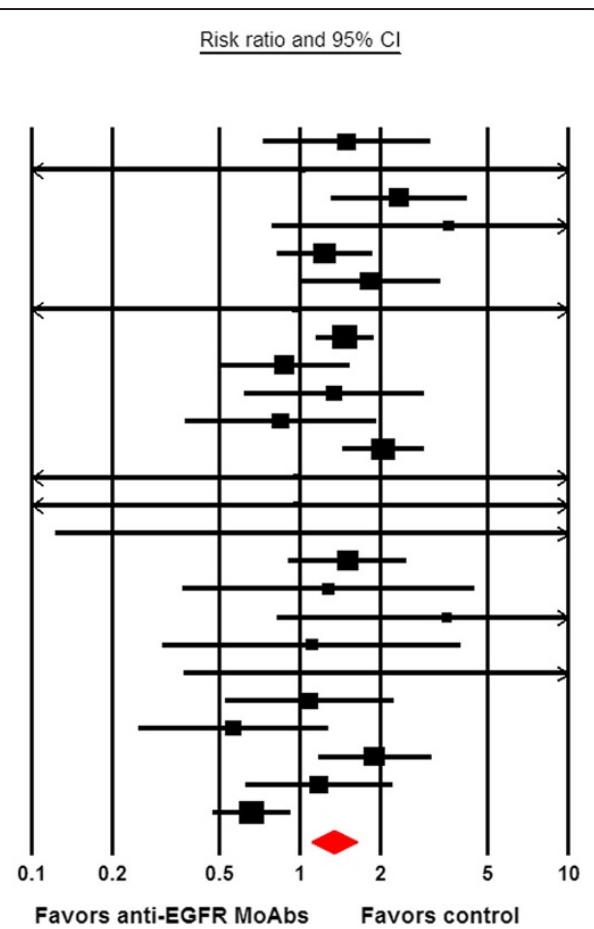

Figure 2 Relative risk of severe infections associated with anti-EGFR MoAbs versus control. EGFR, epidermal growth factor receptor; MoAbs, monoclonal antibodies. 


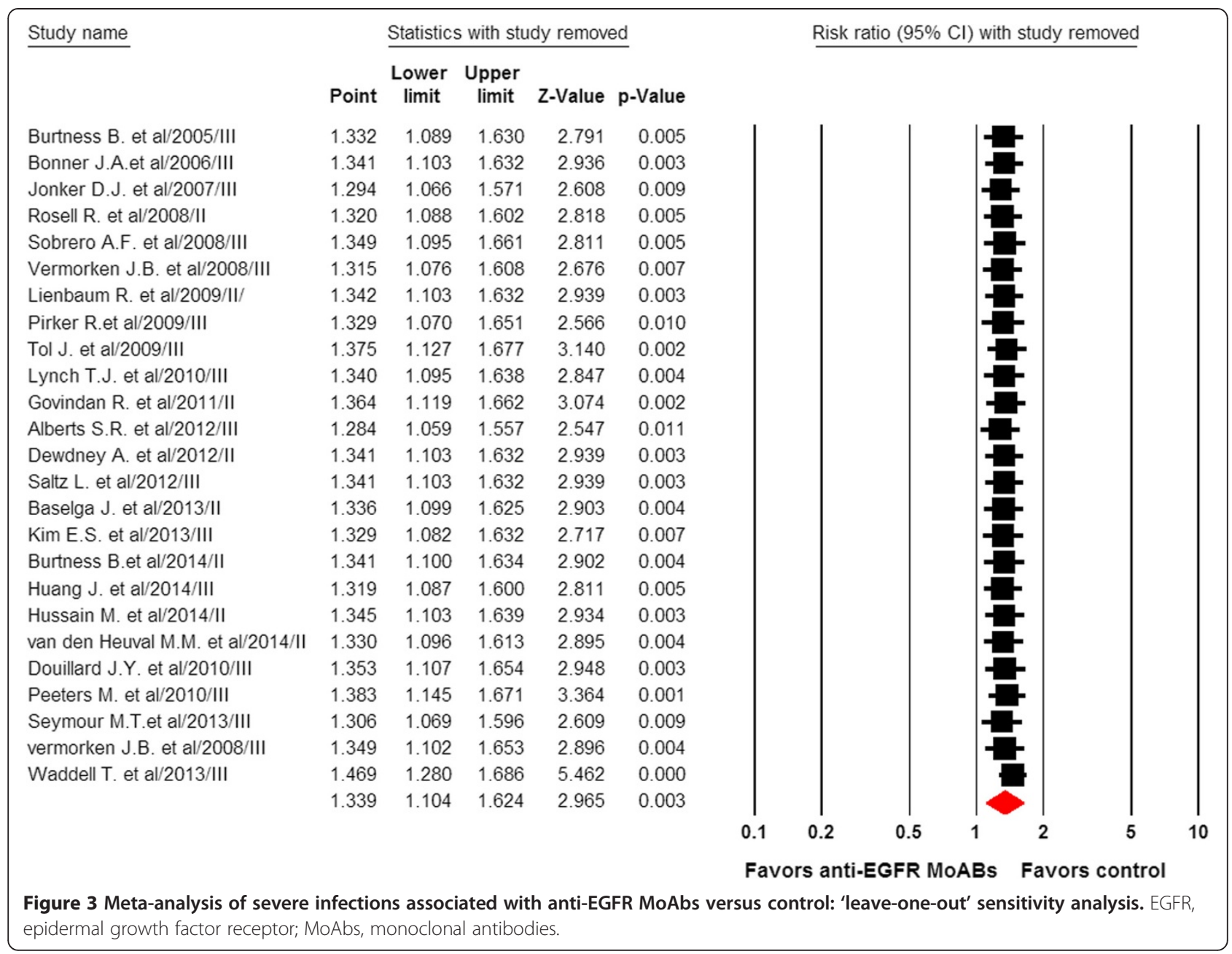

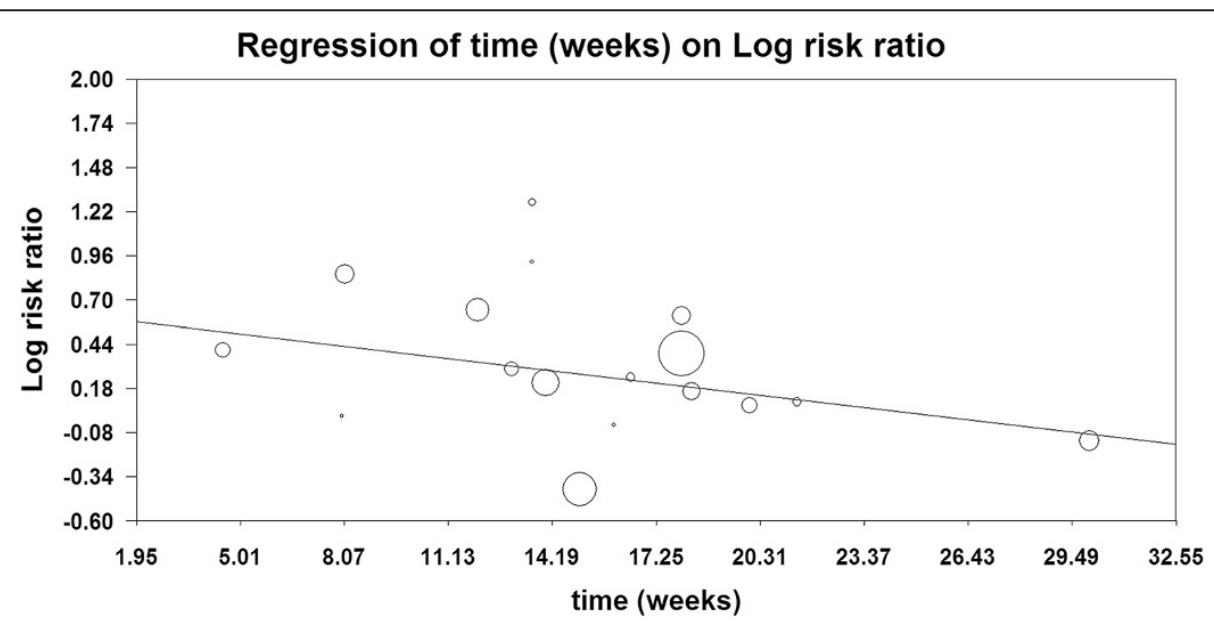

Figure 4 Meta-regression analysis of trends between treatment duration and severe relative risk: symbols: each study is represented by a circle the diameter of which is proportional to its statistical weight. 
Table 2 Relative risk of severe infectious events with EGFR-MoAbs according to tumor types, EGFR-MoAbs, concomitant therapies and phases of trials

\begin{tabular}{|c|c|c|c|c|c|c|}
\hline \multirow[t]{2}{*}{ Groups } & \multirow{2}{*}{$\begin{array}{l}\text { Studies, } \\
\text { number }\end{array}$} & \multicolumn{2}{|c|}{ Severe infectious events, number/total, number } & \multirow[t]{2}{*}{ RR $(95 \% \mathrm{Cl})$} & \multirow[t]{2}{*}{$P$ value } & \multirow{2}{*}{$\begin{array}{l}P \text { value } \\
\text { for group } \\
\text { difference }\end{array}$} \\
\hline & & EGFR-MoAbs & Control & & & \\
\hline \multicolumn{7}{|l|}{ Tumor types } \\
\hline CRC & 11 & $276 / 3801$ & $181 / 3808$ & $1.42(1.05$ to 1.93$)$ & 0.024 & 0.001 \\
\hline NSCLC & 7 & 199/1341 & $137 / 1344$ & $1.45(1.19$ to 1.77$)$ & $<0.001$ & \\
\hline Head and neck cancer & 4 & $64 / 810$ & $43 / 810$ & $1.48(1.02$ to 2.13$)$ & 0.037 & \\
\hline Others & 4 & $62 / 494$ & $77 / 397$ & 0.72 (0.53 to 0.97$)$ & 0.033 & \\
\hline \multicolumn{7}{|l|}{ Anti-EGFR MoAbs } \\
\hline Cetuximab & 21 & $467 / 4548$ & $299 / 4465$ & $1.52(1.33$ to 1.75$)$ & $<0.001$ & 0.092 \\
\hline Panitumumab & 5 & 134/1898 & 139/1894 & 0.99 (0.62 to 1.60$)$ & 0.98 & \\
\hline \multicolumn{7}{|l|}{ Concomitant therapies } \\
\hline Cisplatin & 8 & $233 / 1690$ & $148 / 1608$ & $1.48(1.22$ to 1.79$)$ & $<0.001$ & 0.30 \\
\hline Irinotecan & 4 & $100 / 942$ & $68 / 999$ & 1.53 (1.12 to 2.10$)$ & 0.008 & \\
\hline Oxaliplatin & 8 & $192 / 2892$ & $172 / 2847$ & $0.97(0.58$ to 1.61$)$ & 0.90 & \\
\hline Radiotherapy & 3 & $13 / 312$ & $11 / 313$ & 0.99 (0.47 to 2.10$)$ & 0.98 & \\
\hline Others & 3 & $73 / 610$ & $39 / 592$ & 1.80 (1.24 to 2.62$)$ & 0.002 & \\
\hline \multicolumn{7}{|l|}{ Phases of trials } \\
\hline Phase II & 9 & $35 / 514$ & $21 / 422$ & 1.26 (0.75 to 2.12$)$ & 0.39 & 0.82 \\
\hline Phase III & 17 & $566 / 5932$ & $417 / 593$ & $1.34(1.08$ to 1.67$)$ & 0.008 & \\
\hline Overall & 26 & $601 / 6446$ & $438 / 6359$ & 1.34 (1.10 to 1.62$)$ & 0.003 & NA \\
\hline
\end{tabular}

$\mathrm{Cl}$, confidence interval; CRC, colorectal cancer; EGFR, epidermal growth factor receptor; MoAbs, monoclonal antibodies; NA, not available; NSCLC, non-small-cell lung cancer; RR, relative risk.

cisplatin (RR 1.48, 95\%CI: 1.22 to $1.79, P<0.001$ ) and irinotecan (RR 1.53, 95\% CI: 1.12 to $2.10, P=0.008$ ), while anti-EGFR-MoAbs in combination with oxaliplatin (RR $0.97,95 \% \mathrm{CI}: 0.58$ to $1.61, P=0.90$ ) and radiotherapy (RR $0.99,95 \% \mathrm{CI}: 0.47$ to $2.10, P=0.98$ ) did not increase the risk of severe infections. However, no significant difference in RRs of severe infections was found among these concomitant therapies $(P=0.30)$. Additionally, we did sub-group analysis according to the phase of trials (phase II versus phase III). Patients from phase III trials had an RR of 1.34 (95\%CI: 1.08 to $1.67, P=0.008$ ), while patients from phase II studies had an RR of 1.26 (95\%CI: 0.75 to $2.12, P=0.39$, Table 2 ).

\section{Risk of severe and fatal infections by specific types}

Individual specified and non-specified causes of severe and fatal infections are listed in Table 3. Of those severe infections that were specified, the most common events for severe infections were febrile neutropenia (47.8\%). We then calculated the risk of severe infections stratifying trials according to specific type of infections. Our results showed that the use of anti-EGFR MoAbs significantly increased the risk of severe sepsis (RR 4.30, 95\%CI: 1.80 to $10.27, P=0.001$ ), while a non-significantly increased risk of febrile neutropenia (RR 1.09, 95\% CI: 0.86 to 1.38 , $P=0.68$ ) and pneumonia (RR $1.11,95 \% \mathrm{CI}: 0.72$ to 1.70 ,
$P=0.64)$ was observed. Of the 24 fatal infections on the treatment arms and 11 fatal infections on the control arms, $33.3 \%$ and $18.2 \%$ were of non-specified etiology, respectively. Of those fatal infections that were specified, the most common events for fatal infections were sepsis (37.5\%). When we calculated the risk of fatal infections, stratifying trials according to specific types of infections, a non-significantly increased risk of pneumonia (RR 1.46, 95\%CI: 0.39 to $5.48, P=0.56$ ) and sepsis (RR $1.54,95 \% \mathrm{CI}$ : 0.50 to $4.74, P=0.45$ ) was observed (Table 3 ).

\section{Publication bias}

No publication bias was detected for the primary endpoint of this study (RR of severe infections) by the funnel plot (Figure 5), Egger's test and Begg's test (RR of severe infections: Begg's test $P=0.98$; Egger's test $P=0.73$ ).

\section{Discussion}

Infections are emerging complications of many MoAbs and concerns have arisen regarding the risk of infections with the use of these drugs. In 2007, Rafailidis et al. [45] performed a systematic review to investigate the incidence of infectious complications of several MoAbs including trastuzumab, alemtuzumab, bevacizumab, cetuximab and rituximab. Based on a single trial, there was a higher rate of severe infections in patients receiving cetuximab. Then, 
Table 3 Severe and fatal infectious events with EGFR-MoAbs by specific types

\begin{tabular}{|c|c|c|c|c|}
\hline & \multicolumn{2}{|c|}{ Infectious events, number/total, number } & \multirow[t]{2}{*}{ RR $(95 \% \mathrm{Cl})$} & \multirow[t]{2}{*}{$P$ value } \\
\hline & EGFR-MoAbs & Control & & \\
\hline \multicolumn{5}{|l|}{ Severe infections } \\
\hline Unspecified & $236 / 2844$ & $144 / 2829$ & $1.57(1.16$ to 2.13$)$ & 0.004 \\
\hline Specified & $365 / 7450$ & $294 / 7347$ & $1.18(0.95$ to 1.47$)$ & 0.14 \\
\hline Febrile neutropenia & $287 / 4551$ & $221 / 4579$ & 1.09 (0.86 to 1.38$)$ & 0.68 \\
\hline Pneumonia & $45 / 1605$ & $37 / 1527$ & $1.11(0.72$ to 1.70$)$ & 0.64 \\
\hline Sepsis & $33 / 1294$ & $6 / 1241$ & $4.30(1.80$ to 10.27$)$ & 0.001 \\
\hline \multicolumn{5}{|l|}{ Fatal infections } \\
\hline Unspecified & $8 / 1471$ & $2 / 1424$ & 2.39 (0.58 to 9.83$)$ & 0.23 \\
\hline Specified & $16 / 2486$ & $9 / 2305$ & 1.43 (0.64 to 3.18$)$ & 0.38 \\
\hline Pneumonia & $6 / 1336$ & $3 / 1261$ & $1.46(0.39$ to 5.48$)$ & 0.56 \\
\hline Febrile neutropenia & $1 / 321$ & $1 / 321$ & $1.00(0.11$ to 9.51$)$ & 1.00 \\
\hline Sepsis & $9 / 829$ & $5 / 732$ & 1.54 (0.50 to 4.74$)$ & 0.45 \\
\hline
\end{tabular}

$\mathrm{Cl}$, confidence interval; EGFR, epidermal growth factor receptor; MoAbs, monoclonal antibodies; RR, relative risk.

Lee et al. [46] in 2012 conducted a national cohort study of 1,083 head and neck cancer patients and found that cetuximab therapy was not statistically associated with an increased infection rate in head and neck cancer patients. As a result, the incidence and risk of infections associated with anti-EGFR MoAbs has not been well defined.

Our meta-analysis includes a total of 14,060 patients from twenty six RCTs investigating anti-EGFR MoAbs for the treatment of cancers. To the best of our knowledge, this is the first large study of RCTs demonstrating a significant increase in the risk of severe infections ( $\geq$ grade 3 ) with the use of anti-EGFR MoAbs in cancer patients. Our analysis finds that the risk of developing a severe infection is 1.34-fold higher in patients treated with anti-EGFR MoAbs, while the use of anti-EGFR MoAbs does not significantly increase the risk of fatal infections.
Sensitivity analysis indicates that the significance estimate of pooled RRs of severe infection is stable and reliable. We also performed a meta-regression analysis to investigate the association between cumulative anti-EGFR MoAbs exposure and severe infections. The result indicates that severe infections might possibly occur early in the treatment with anti-EGFR MoAbs. In contrast with our result, the study conducted by Burtness et al. [5] showed that the increased risk of neutropenia with cetuximab/cisplatin compared with placebo/cisplatin was associated with longer duration of therapy. As a result, further prospective studies are still needed to address this issue. We also investigated the outcome of anti-EGFR MoAbs-associated severe infections. Our study shows that the overall incidence of fatal infections with anti-EGFR MoAbs is $0.8 \%$. Given that the absolute risk of fatal infections is low, the

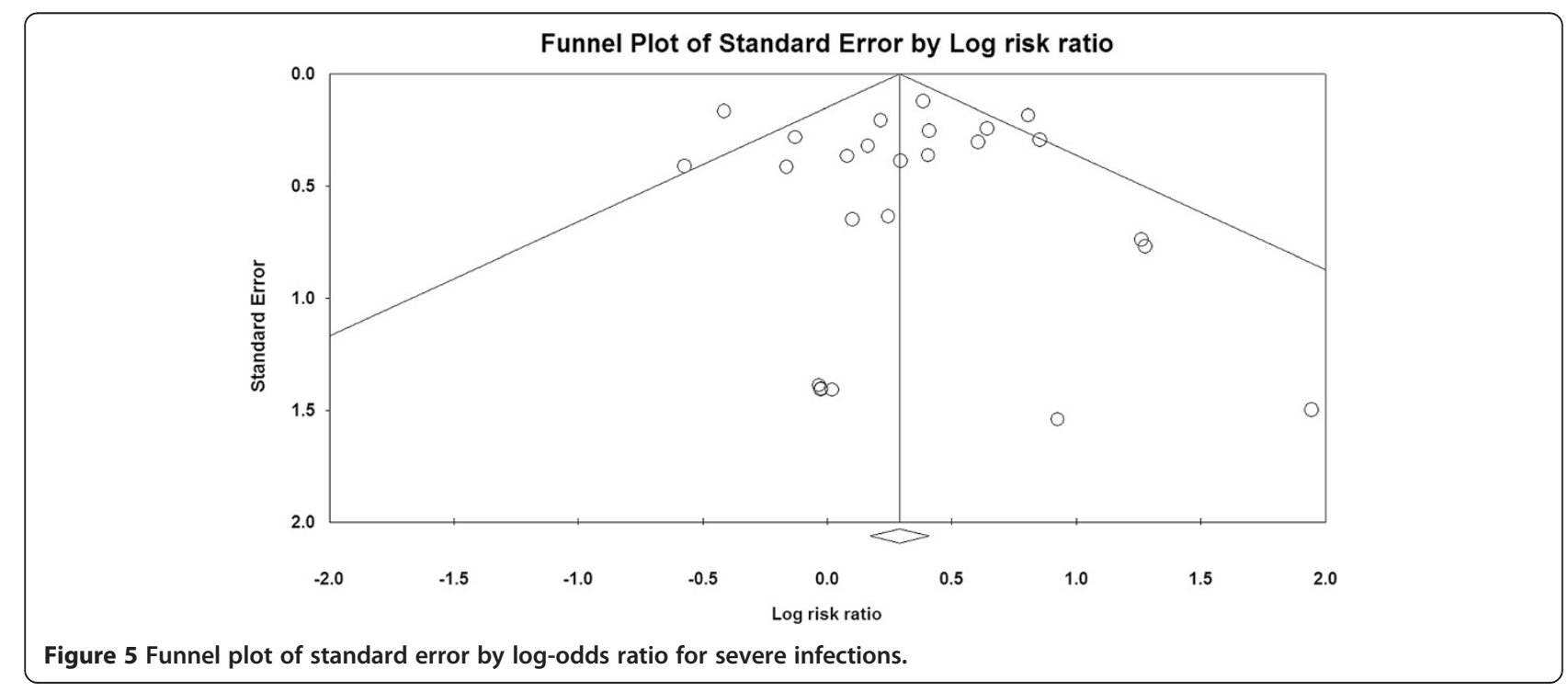


use of anti-EGFR-MoAbs should be considered in the context of overall survival benefits. Because anti-EGFR MoAbs are increasingly used in cancer patients, it is particularly important for all health care practitioners and patients to understand and recognize the risk of severe and fatal infection.

Because risk factors for severe infections with antiEGFR MoAbs are poorly understood, we carried out a subgroup analysis to identify potential risk factors for anti-EGFR MoAbs related-infections. When stratified by tumor type, a significantly increased risk of severe infections with anti-EGFR MoAbs is observed in colorectal cancer, non-small-cell lung cancer, and head and neck cancer. Interestingly, no increased risk of severe infections is observed in patients with other tumor types receiving anti-EGFR MoAbs. The risk of severe infections varies significantly with different tumor types $(P=0.001)$, reflecting the nature of the underlying tumor biology or associated treatment. Notably, our study shows that antiEGFR MoAbs significantly increase the risk of severe infections when used in conjunction with cisplatin or irinotecan. This result may reflect an interaction between anti-EGFR MoAbs and certain chemotherapeutic agents in causing severe infections. However, the risk of severe infections dose not significantly vary with concomitant therapies $(P=0.30)$. We also performed sub-group analysis according to antiEGFR MoAbs and demonstrated that the use of cetuximab significantly increases the risk of severe infections, but this was not the case with panitumumab. Additionally, no significant differences in the risk of severe infections with anti-EGFR MoAbs were observed according to the phase of the trials. Based on our findings, the following approaches may be considered to reduce the association of anti-EGFR MoAbs with risk of severe infections. Before the initiation of anti-EGFR MoAbs, clinicians must fully treat patients with any active infection and must monitor patients during the course of anti-EGFR MoAbs treatment. Clinicians should be cautious when adding anti-EGFR MoAbs to the therapies for the treatment of colorectal cancer, non-small-cell lung cancer, and head and neck cancer, especially when used in conjunction with cisplatin or irinotecan.

Despite the size of this meta-analysis, our study has several limitations. First, all included studies were conducted at major academic institutions among patients with adequate major organ function and may not reflect the general patient population in the community or patients with organ dysfunction. It is conceivable that the true incidences and risk of treatment-related infections from this study may be underestimated. Second, these studies were conducted at various institutions by different investigators internationally and may have potential bias in reported incidences or specification of severe infections. Severe infections are not primary outcome measures in the included studies. The reported incidence of severe infections has significant heterogeneity among the included studies. Nevertheless, we attempted to adjust for the heterogeneity using a random-effects model to calculate the incidence of severe and fatal infections. Third, our study shows that the RR of fatal infection is higher in patients receiving anti-EGFR MoAbs than in controls, but is not statistically significant. This observation might be limited by sample size. Finally, this is a meta-analysis at study level; therefore, confounding factors at the patient level cannot be assessed properly and incorporated into the analysis.

\section{Conclusions}

In conclusion, this study has demonstrated that the addition of anti-EGFR MoAbs to concurrent antineoplastic therapy is associated with an increased risk of severe infections in cancer patients. The use of cisplatin or irinotecan may increase the risk of severe infections associated with anti-EGFR MoAbs. The increased risk of severe infections associated with anti-EGFR MoAbs may vary with tumor types. Early detection and effective management of infections that can occur with anti-EGFR MoAbs is crucial for safer use of this drug. Further studies are still recommended to investigate risk reduction and the possible mechanism of anti-EGFR MoAbs induced infections.

\section{Abbreviations}

ASCO: American Society of Clinical Oncology; Cls: confidence intervals; EGFR: epidermal growth factor receptor; ESMO: European Society of Medical Oncology; FDA: Food and Drug Administration; IgG1: immunoglobulin G1; MoAbs: monoclonal antibodies; NCI-CTC: National Cancer Institute's common terminology criteria; RCTs: randomized controlled trials; RRs: relative risks; VEGF: vascular endothelial growth factor.

\section{Competing interests}

All authors declare that they have no competing interests.

\section{Authors' contributions}

Concept and design: XMG and SF. Search and collection of data: XMG and SF. Analysis of data and interpretation: QZ and XMG. Tables and figures: WXQ. Writing the manuscript and review: WXQ and SF. All authors read and approved the final manuscript.

Received: 18 June 2014 Accepted: 3 October 2014

Published online: 05 November 2014

\section{References}

1. Goffin JR, Zbuk K: Epidermal growth factor receptor: pathway, therapies, and pipeline. Clin Ther 2013, 35:1282-1303.

2. Normanno N, De Luca A, Bianco C, Strizzi L, Mancino M, Maiello MR, Carotenuto A, De Feo G, Caponigro F, Salomon DS: Epidermal growth factor receptor (EGFR) signaling in cancer. Gene 2006, 366:2-16.

3. Kari C, Chan TO, Rocha de Quadros M, Rodeck U: Targeting the epidermal growth factor receptor in cancer: apoptosis takes center stage. Cancer Res 2003, 63:1-5.

4. Cunningham D, Humblet $Y$, Siena S, Khayat D, Bleiberg $H$, Santoro A, Bets D, Mueser M, Harstrick A, Verslype C, Chau I, Van Cutsem E: Cetuximab monotherapy and cetuximab plus irinotecan in irinotecan-refractory metastatic colorectal cancer. N Engl J Med 2004, 351:337-345.

5. Burtness B, Goldwasser MA, Flood W, Mattar B, Forastiere AA: Phase III randomized trial of cisplatin plus placebo compared with cisplatin plus 
cetuximab in metastatic/recurrent head and neck cancer: an Eastern Cooperative Oncology Group study. J Clin Oncol 2005, 23:8646-8654.

6. Van Cutsem E, Peeters M, Siena S, Humblet Y, Hendlisz A, Neyns B, Canon JL, Van Laethem JL, Maurel J, Richardson G, Wolf M, Amado RG: Open-label phase III trial of panitumumab plus best supportive care compared with best supportive care alone in patients with chemotherapy-refractory metastatic colorectal cancer. J Clin Oncol 2007, 25:1658-1664.

7. Su X, Lacouture ME, Jia Y, Wu S: Risk of high-grade skin rash in cancer patients treated with cetuximab-an antibody against epidermal growth factor receptor: systemic review and meta-analysis. Oncology 2009, 77:124-133.

8. Qi WX, Sun YJ, Shen Z, Yao Y: Risk of anti-EGFR monoclonal antibody-related skin rash: an up-to-date meta-analysis of 25 randomized controlled trials. $J$ Chemother. in press.

9. Cao Y, Liao C, Tan A, Liu L, Gao F: Meta-analysis of incidence and risk of hypomagnesemia with cetuximab for advanced cancer. Chemotherapy 2010, 56:459-465.

10. Petrelli F, Borgonovo K, Cabiddu M, Ghilardi M, Barni S: Risk of anti-EGFR monoclonal antibody-related hypomagnesemia: systematic review and pooled analysis of randomized studies. Expert Opin Drug Saf 2012, 11:S9-S19.

11. Chen P, Wang L, Li H, Liu B, Zou Z: Incidence and risk of hypomagnesemia in advanced cancer patients treated with cetuximab: a meta-analysis. Oncol Lett 2013, 5:1915-1920.

12. Cao Y, Liu L, Liao C, Tan A, Gao F: Meta-analysis of incidence and risk of hypokalemia with cetuximab-based therapy for advanced cancer. Cancer Chemother Pharmacol 2010, 66:37-42.

13. Vermorken JB, Mesia R, Rivera F, Remenar E, Kawecki A, Rottey S, Erfan J, Zabolotnyy D, Kienzer HR, Cupissol D, Peyrade F, Benasso M, Vynnychenko I, De Raucourt D, Bokemeyer C, Schueler A, Amellal N, Hitt R: Platinum-based chemotherapy plus cetuximab in head and neck cancer. $N$ Engl J Med 2008, 359:1116-1127.

14. Alberts SR, Sargent DJ, Nair S, Mahoney MR, Mooney M, Thibodeau SN, Smyrk TC, Sinicrope FA, Chan E, Gill S, Kahlenberg MS, Shields AF, Quesenberry JT, Webb TA, Farr GH Jr, Pockaj BA, Grothey A, Goldberg RM: Effect of oxaliplatin, fluorouracil, and leucovorin with or without cetuximab on survival among patients with resected stage III colon cancer: a randomized trial. JAMA 2012, 307:1383-1393.

15. Seymour MT, Brown SR, Middleton G, Maughan T, Richman S, Gwyther S, Lowe C, Seligmann JF, Wadsley J, Maisey N, Chau I, Hill M, Dawson L, Falk S, O'Callaghan A, Benstead K, Chambers P, Oliver A, Marshall H, Napp V, Quirke P: Panitumumab and irinotecan versus irinotecan alone for patients with KRAS wild-type, fluorouracil-resistant advanced colorectal cancer (PICCOLO): a prospectively stratified randomised trial. Lancet Oncol 2013, 14:749-759.

16. ClinicalTrials.gov [http://www.ClinicalTrials.gov]

17. CTEP Cancer Therapy Evaluation Program [http://ctep.cancer.gov]

18. Choueiri TK, Schutz FA, Je Y, Rosenberg JE, Bellmunt J: Risk of arterial thromboembolic events with sunitinib and sorafenib: a systematic review and meta-analysis of clinical trials. J Clin Oncol 2010, 28:2280-2285.

19. Zintzaras $E$, loannidis JP: Heterogeneity testing in meta-analysis of genome searches. Genet Epidemiol 2005, 28:123-137.

20. DerSimonian R, Laird N: Meta-analysis in clinical trials. Control Clin Trials 1986, 7:177-188.

21. Sterne JA, Gavaghan D, Egger M: Publication and related bias in meta-analysis: power of statistical tests and prevalence in the literature. J Clin Epidemio/ 2000, 53:1119-1129.

22. Jonker DJ, O'Callaghan CJ, Karapetis CS, Zalcberg JR, Tu D, Au HJ, Berry SR, Krahn M, Price T, Simes RJ, Tebbutt NC, van Hazel G, Wierzbicki R, Langer C, Moore MJ: Cetuximab for the treatment of colorectal cancer. N Engl J Med 2007, 357:2040-2048.

23. Borner M, Koeberle D, Von Moos R, Saletti P, Rauch D, Hess V, Trojan A, Helbling D, Pestalozzi B, Caspar C, Ruhstaller T, Roth A, Kappeler A, Dietrich D, Lanz D, Mingrone W, Swiss Group for Clinical Cancer Research (SAKK), Bern, Switzerland: Adding cetuximab to capecitabine plus oxaliplatin (XELOX) in first-line treatment of metastatic colorectal cancer: a randomized phase II trial of the Swiss Group for Clinical Cancer Research SAKK. Ann Oncol 2008, 19:1288-1292.

24. Sobrero AF, Maurel J, Fehrenbacher L, Scheithauer W, Abubakr YA, Lutz MP, Vega-Villegas ME, Eng C, Steinhauer EU, Prausova J, Lenz HJ, Borg C, Middleton G, Kröning H, Luppi G, Kisker O, Zubel A, Langer C, Kopit J, Burris HA 3rd: EPIC: phase III trial of cetuximab plus irinotecan after fluoropyrimidine and oxaliplatin failure in patients with metastatic colorectal cancer. J Clin Oncol 2008, 26:2311-2319.
25. Tol J, Koopman M, Rodenburg CJ, Cats A, Creemers GJ, Schrama JG, Erdkamp FL, Vos AH, Mol L, Antonini NF, Punt CJ: A randomised phase III study on capecitabine, oxaliplatin and bevacizumab with or without cetuximab in first-line advanced colorectal cancer, the CAIRO2 study of the Dutch Colorectal Cancer Group (DCCG). An interim analysis of toxicity. Ann Oncol 2008, 19:734-738.

26. Tol J, Koopman M, Cats A, Rodenburg CJ, Creemers GJ, Schrama JG, Erdkamp FL, Vos AH, van Groeningen CJ, Sinnige HA, Richel DJ, Voest EE, Dijkstra JR, Vink-Börger ME, Antonini NF, Mol L, van Krieken JH, Dalesio O, Punt CJ: Chemotherapy, bevacizumab, and cetuximab in metastatic colorectal cancer. N Engl J Med 2009, 360:563-572.

27. Dewdney A, Cunningham D, Tabernero J, Capdevila J, Glimelius B, Cervantes A, Tait D, Brown G, Wotherspoon A, Gonzalez de Castro D, Chua YJ, Wong R, Barbachano Y, Oates J, Chau I: Multicenter randomized phase II clinical trial comparing neoadjuvant oxaliplatin, capecitabine, and preoperative radiotherapy with or without cetuximab followed by total mesorectal excision in patients with high-risk rectal cancer (EXPERT-C). J Clin Oncol 2012, 30:1620-1627.

28. Saltz L, Badarinath S, Dakhil S, Bienvenu B, Harker WG, Birchfield G, Tokaz LK, Barrera D, Conkling PR, O'Rourke MA, Richards DA, Reidy D, Solit D, Vakiani E, Capanu M, Scales A, Zhan F, Boehm KA, Asmar L, Cohn A: Phase III trial of cetuximab, bevacizumab, and 5-fluorouracil/leucovorin vs. FOLFOX-bevacizumab in colorectal cancer. Clin Colorectal Cancer 2012, 11:101-111.

29. Huang J, Nair SG, Mahoney MR, Nelson GD, Shields AF, Chan E, Goldberg RM, Gill S, Kahlenberg MS, Quesenberry JT, Thibodeau SN, Smyrk TC, Grothey A, Sinicrope FA, Webb TA, Farr GH Jr, Pockaj BA, Berenberg JL, Mooney M, Sargent DJ, Alberts SR, Alliance for Clinical Trials in Oncology: Comparison of FOLFIRI with or without cetuximab in patients with resected stage III Colon Cancer; NCCTG (Alliance) Intergroup Trial N0147. Clin Colorectal Cancer 2014, 13:100-109.

30. Douillard JY, Siena S, Cassidy J, Tabernero J, Burkes R, Barugel M, Humblet Y, Bodoky G, Cunningham D, Jassem J, Rivera F, Kocákova I, Ruff P, Błasińska-Morawiec M, Šmakal M, Canon JL, Rother M, Oliner KS, Wolf M Gansert J: Randomized, phase III trial of panitumumab with infusional fluorouracil, leucovorin, and oxaliplatin (FOLFOX4) versus FOLFOX4 alone as first-line treatment in patients with previously untreated metastatic colorectal cancer: the PRIME study. J Clin Oncol 2010, 28:4697-4705.

31. Peeters M, Price TJ, Cervantes A, Sobrero AF, Ducreux M, Hotko Y, Andre T, Chan E, Lordick F, Punt CJ, Strickland AH, Wilson G, Ciuleanu TE, Roman L, Van Cutsem E, Tzekova V, Collins S, Oliner KS, Rong A, Gansert J: Randomized phase III study of panitumumab with fluorouracil, leucovorin, and irinotecan (FOLFIRI) compared with FOLFIRI alone as second-line treatment in patients with metastatic colorectal cancer. J Clin Oncol 2010, 28:4706-4713.

32. Lilenbaum R, Wang X, Gu L, Kirshner J, Lerro K, Vokes E: Randomized phase Il trial of docetaxel plus cetuximab or docetaxel plus bortezomib in patients with advanced non-small-cell lung cancer and a performance status of 2: CALGB 30402. J Clin Oncol 2009, 27:4487-4491.

33. Rosell R, Robinet G, Szczesna A, Ramlau R, Constenla M, Mennecier BC, Pfeifer W, O'Byrne KJ, Welte T, Kolb R, Pirker R, Chemaissani A, Perol M, Ranson MR, Ellis PA, Pilz K, Reck M: Randomized phase II study of cetuximab plus cisplatin/vinorelbine compared with cisplatin/vinorelbine alone as first-line therapy in EGFR-expressing advanced non-small-cell lung cancer. Ann Oncol 2008, 19:362-369.

34. Pirker R, Pereira JR, Szczesna A, von Pawel J, Krzakowski M, Ramlau R, Vynnychenko I, Park K, Yu CT, Ganul V, Roh JK, Bajetta E, O'Byrne K, de Marinis F, Eberhardt W, Goddemeier T, Emig M, Gatzemeier U, FLEX Study Team: Cetuximab plus chemotherapy in patients with advanced non-small-cell lung cancer (FLEX): an open-label randomised phase III trial. Lancet 2009, 373:1525-1531.

35. Lynch TJ, Patel T, Dreisbach L, McCleod M, Heim WJ, Hermann RC, Paschold E, lannotti NO, Dakhil S, Gorton S, Pautret V, Weber MR, Woytowitz D: Cetuximab and first-line taxane/carboplatin chemotherapy in advanced non-small-cell lung cancer: results of the randomized multicenter phase III trial BMS099. J Clin Oncol 2010, 28:911-917.

36. Govindan R, Bogart J, Stinchcombe T, Wang X, Hodgson L, Kratzke R, Garst J, Brotherton T, Vokes EE: Randomized phase II study of pemetrexed, carboplatin, and thoracic radiation with or without cetuximab in patients with locally advanced unresectable non-small-cell lung cancer: Cancer and Leukemia Group B trial 30407. J Clin Oncol 2011, 29:3120-3125. 
37. Kim ES, Neubauer M, Cohn A, Schwartzberg L, Garbo L, Caton J, Robert F, Reynolds C, Katz T, Chittoor S, Simms L, Saxman S: Docetaxel or pemetrexed with or without cetuximab in recurrent or progressive non-small-cell lung cancer after platinum-based therapy: a phase 3, open-label, randomised trial. Lancet Oncol 2013, 14:1326-1336.

38. van den Heuvel MM, Uyterlinde W, Vincent AD, de Jong J, Aerts J, Koppe F, Knegjens J, Codrington H, Kunst PW, Dieleman E, Verheij M, Belderbos J: Additional weekly Cetuximab to concurrent chemoradiotherapy in locally advanced non-small cell lung carcinoma: efficacy and safety outcomes of a randomized, multi-center phase II study investigating. Radiother Oncol 2014, 110:126-131.

39. Bonner JA, Harari PM, Giralt J, Azarnia N, Shin DM, Cohen RB, Jones CU, Sur R, Raben D, Jassem J, Ove R, Kies MS, Baselga J, Youssoufian H, Amellal N, Rowinsky EK, Ang KK: Radiotherapy plus cetuximab for squamous-cell carcinoma of the head and neck. N Engl J Med 2006, 354:567-578.

40. Vermorken JB, Stohlmacher-Williams J, Davidenko I, Licitra L, Winquist E, Villanueva C, Foa P, Rottey S, Skladowski K, Tahara M, Pai VR, Faivre S, Blajman CR, Forastiere AA, Stein BN, Oliner KS, Pan Z, Bach BA, SPECTRUM Investigators: Cisplatin and fluorouracil with or without panitumumab in patients with recurrent or metastatic squamous-cell carcinoma of the head and neck (SPECTRUM): an open-label phase 3 randomised trial. Lancet Oncol 2013, 14:697-710.

41. Baselga J, Gomez P, Greil R, Braga S, Climent MA, Wardley AM, Kaufman B, Stemmer SM, Pego A, Chan A, Goeminne JC, Graas MP, Kennedy MJ, Ciruelos Gil EM, Schneeweiss A, Zubel A, Groos J, Melezínková H, Awada A: Randomized phase II study of the anti-epidermal growth factor receptor monoclonal antibody cetuximab with cisplatin versus cisplatin alone in patients with metastatic triple-negative breast cancer. J Clin Oncol 2013, 31:2586-2592.

42. Hussain M, Daignault S, Agarwal N, Grivas PD, Siefker-Radtke AO, Puzanov I, Macvicar GR, Levine EG, Srinivas S, Twardowski P, Eisenberger MA, Quinn DI, Vaishampayan UN, Yu EY, Dawsey S, Day KC, Day ML, Al-Hawary M, Smith DC: A randomized phase 2 trial of gemcitabine/cisplatin with or without cetuximab in patients with advanced urothelial carcinoma. Cancer 2014, 120:2684-2692

43. Burtness B, Powell M, Catalano P, Berlin J, Liles DK, Chapman AE, Mitchell E, Benson $A B$ : Randomized phase II trial of irinotecan/docetaxel or irinotecan/docetaxel plus cetuximab for metastatic pancreatic cancer: an eastern cooperative oncology group study. Am J Clin Oncol. in press.

44. Waddell T, Chau I, Cunningham D, Gonzalez D, Okines AF, Okines C, Wotherspoon A, Saffery C, Middleton G, Wadsley J, Ferry D, Mansoor W, Crosby T, Coxon F, Smith D, Waters J, Iveson T, Falk S, Slater S, Peckitt C, Barbachano $Y$ : Epirubicin, oxaliplatin, and capecitabine with or without panitumumab for patients with previously untreated advanced oesophagogastric cancer (REAL3): a randomised, open-label phase 3 trial. Lancet Oncol 2013, 14:481-489.

45. Rafailidis PI, Kakisi OK, Vardakas K, Falagas ME: Infectious complications of monoclonal antibodies used in cancer therapy: a systematic review of the evidence from randomized controlled trials. Cancer 2007, 109:2182-2189.

46. Lee CC, Ho HC, Hsiao SH, Huang TT, Lin HY, Li SC, Chou P, Su YC: Infectious complications in head and neck cancer patients treated with cetuximab: propensity score and instrumental variable analysis. PLOS One 2012, 7:e50163.

\section{doi:10.1186/s12916-014-0203-5}

Cite this article as: Qi et al:: Incidence and risk of severe infections associated with anti-epidermal growth factor receptor monoclonal antibodies in cancer patients: a systematic review and meta-analysis. BMC Medicine 2014 12:203.

\section{Submit your next manuscript to BioMed Central and take full advantage of:}

- Convenient online submission

- Thorough peer review

- No space constraints or color figure charges

- Immediate publication on acceptance

- Inclusion in PubMed, CAS, Scopus and Google Scholar

- Research which is freely available for redistribution

Submit your manuscript at www.biomedcentral.com/submit
C Biomed Central 